The Journal of Engineering and Exact Sciences - jCEC, Vol. 06 N. 02 (2020)

journal homepage: https://periodicos.ufv.br/ojs/jcec

doi: 10.18540/jecvl6iss2pp0147-0151

OPEN ACCESS - ISSN: 2527-1075

\title{
QUESTIONING THE RELEVANCE OF SOLUTION pH CALCULATION
}

\section{QUESTIONANDO A RELEVÂNCIA DO CÁLCULO DE pH DE SOLUÇÕES}

\author{
A.F. Oliveira ${ }^{1 *}$ \\ ${ }^{1}$ Universidade Federal de Viçosa, Department of Chemistry. \\ ${ }^{*}$ Corresponding author. Universidade Federal de Viçosa, Department of Chemistry, Viçosa, Brazil, Phone: +553136126610 \\ e-mail addressl: andref.oliveira@ufv.br
}

\begin{tabular}{l} 
A R T I C L E I N F O \\
\hline Article history: \\
Received 2020-04-09 \\
Accepted 2020-06-17 \\
Available online 2020-06-17 \\
p a l a v r a s - ch h v ve \\
Segundo ano da Graduação \\
Químicas de Soluções \\
Resolução de Problemas \\
Ácidos e Bases \\
k e y w o r d s \\
Second-Year Undergraduate \\
Aqueous Solution Chemistry \\
Problem Solving \\
Acids / Bases
\end{tabular}

\begin{abstract}
A B S T R A C T
A brief discussion on the unnecessary calculation of $p H$ in solution was done, as the historical reasons for this need before the invention of commercial pH meter was widely diffused. An alternative approach for acid-base equilibrium evaluation was proposed, without approximation or need of application only for simple solutions. The central aspect for the new approach is the determination of equilibrium concentration of all chemical species in solution, including the strong acid or base concentration for adjusting of $\mathrm{pH}$ of solutions. Therefore, the proposed method allowed the calculation in a mixture, including several polyprotic systems. Two detailed examples were presented. The effective electrical charge parameter was formally defined.
\end{abstract}

\section{R E S U M O}

Uma breve discussão sobre a falta de necessidade do cálculo de pH de soluções é feita, assim como a razão histórica para essa necessidade antes da invenção do pHmetro comercial foi amplamente difundida. Uma proposta alternativa para a avaliação de equilíbrios ácido-base é proposta. O aspecto central dessa nova proposta é a determinação da concentração no equilíbrio de todas as espécies químicas em solução, incluindo de ácido ou bases fortes usadas para o ajuste do $\mathrm{pH}$ das soluções. Assim, dois exemplos detalhados são apresentados. $O$ parâmetro carga elétrica efetiva foi formalmente definido. 
The Journal of Engineering and Exact Sciences - jCEC, Vol. 06 N. 02 (2020)

journal homepage: https://periodicos.ufv.br/ojs/jcec

doi: 10.18540/jcecvl6iss2pp0147-0151

OPEN ACCESS - ISSN: 2527-1075

\section{INTRODUCTION}

There are lots of papers about approximation or rigorous calculation of $\mathrm{pH}$ in aqueous solution.(Uribe, 1998; Matsumoto et al., (2009); Matsumoto, 2005; Pardue et al., 2004; Cepriá et al.,2014; Glaser et al., 2014; Bellová et al., 2018; Po et al., 2001; Harris, 2006; Skoog et al., 2013) For each kind of situation (pure solution, buffer solution, acid-base titration, etc.), there are different proposed solutions. Unfortunately, in real applications, it is rare to have $\mathrm{pH}$ calculations done. It is frustrating for most professionals or students who had spent time working on this subject. Virtually all textbooks present $\mathrm{pH}$ calculations in an equilibrium situation. The fundamental issues with this kind of calculation is the need to have very simplified conditions or the excessive mathematical skills. One important question is: "Is there an easy and comprehensive way to calculate $\mathrm{pH}$ in solution when several acid-base species, such as citric acid, dihydrogen phosphate, and acetic acid, are present?"

Twenty years ago, during an analytical chemistry class, fighting to explain the difference between uses of $\mathrm{pH}$ calculation and the Diagram of Chemical Species Distribution, I had an insight: Why one must calculate $\mathrm{pH}$ ? And when I answered this question adequately, I could see a new world of possibilities.

I will explain my point of view in two ways. First, I will show why, nowadays, $\mathrm{pH}$ calculation is overvalued. Then, I will review why the calculation of $\mathrm{pH}$ was so important. And finally, the way to think in acid-base equilibrium will be more comprehensible and applicable in all areas of chemistry.

To begin, in practice, how one determines the $\mathrm{pH}$ of a solution? Just by measure it! There is a $\mathrm{pH}$ meter in practically every lab. Besides, it is so cheap that someone could buy one for play (measure $\mathrm{pH}$ of a lake, an aquarium, etc.). So, in other words, everyone almost always knows the $\mathrm{pH}$ of a solution. If he/she do not, then he/she can measure it. If someone wants to adjust the $\mathrm{pH}$ of a solution, buffered or not, small additions of a strong base or acid (or even buffer solution) could be added to the medium, and the $\mathrm{pH}$ measurements were done again and again until the desired $\mathrm{pH}$ is reached. So, if $\mathrm{pH}$ measure is so easy, its calculation is usually unnecessary.

The historical reason to calculate $\mathrm{pH}$ is, apparently, and curiously the opposite reason why people do not need to do it today. In the time of Arrhenius, when $\mathrm{pH}$ became an important parameter in solution, there was an easy way to measure $\mathrm{pH}$. Arrhenius, Ostwald, and others had used electric conductivity measurements to determine $\mathrm{pH}$. In this technique, just simple or pure solutions could have the $\mathrm{pH}$ measured. Ostwald's equation of dilution was the beginning of the approximated $\mathrm{pH}$ calculation (Szabadvary et al., 1964). By the end of the nineteenth and beginning of the twentieth century, the laborious potentiometric method, using a hydrogen electrode, started to be replaced by the colorimetric method. But the former, although easy to use, needed $\mathrm{pH}$ standard solutions. So, the era of buffer solutions started (Clark, 1922; Szabadvary et al., 1964). In the beginning, just a few compounds were used because of the production of pure ones was difficult.
The $\mathrm{pH}$ calculation of solutions was justified for several years. The commercial $\mathrm{pH}$ meter was commercialized just in the 1940s (by Beckman), (Science History Institute, 2017) and the invention of the first solid-state electronic calculator was in the early 1960s. Pocket-sized devices became available in the 1970 s, and the personal computer became popular in the 1980s. Nowadays, the $\mathrm{pH}$ of a solution is easily measured in labs or field. And calculations are also friendly done with computers or electronic calculators.

But if the teacher does not teach $\mathrm{pH}$ calculation (neither by Henderson-Hasselbalch Equation), I have another question: What could be teaching about acid-base equilibrium?

I want to share the approach I have been adopting in class with significant improvement over the conventional method of teaching. The main goal of studying acid-base equilibrium is to present and calculate the concentration of all species in solution in a given $\mathrm{pH}$ value. It is a crucial subject for almost all areas of chemistry of solutions. The equilibrium concentration of chemical species permeating hydrophobic membranes, the distribution of analyte species in an HPLC mobile phase, the influence of $\mathrm{pH}$ on reaction rates, and the $\mathrm{pH}$ buffering effects are just a few of the possible examples.

\section{THE THEORICAL APPROACH}

In this approach, (Oliveira, 2009; Oliveira, 2020) I use what I call "the solution triad," which is the matter balance (or Principle of conservation of matter), the balance of electric charge (or Principle of Electroneutrality), and Law of Mass Action. And the critical concepts of analytical concentration and equilibrium concentration. All of them are known but not so commonly used in equilibria teaching. Besides, the acid-base equilibrium will be treated by the Bronsted view.

If a solution contains one or several acid-base equilibria, once $\mathrm{pH}$ is known, all species are also known if their analytical concentrations (c) are known (including situations in which it was used acid or base for $\mathrm{pH}$ correction).

In several somewhat complex situations, this method allows us to determine whether an acid or a base solution was added to the system and also its analytical concentration. That is fantastic!!

It is just due to an equilibrium fraction function $(\alpha)$, which is a direct consequence of the Law of Mass Action and Matter Balance (Eq. 1).

$\alpha(A)=\frac{[A]}{c(A)}$

Remembering balance of matter is the relationship between the analytical concentrations and the equilibrium concentration of all species in the system at equilibrium.

The key aspect of fraction equilibrium is that its value depends only on the system's $\mathrm{pKa}$ and the $\mathrm{pH}$ of the solution. This relationship is not trivial at a glance, but the approach requires the students getting to know how to use the equation for 
the monoprotic system at first (Eqs. 2-3) and then use computer models for polyprotic systems (Eq.4). Excel spreadsheets, addon, and apps were developed for such cases. (Oliveira, 2020b)

$$
\begin{gathered}
\alpha_{0}=\frac{1}{1+10^{p H-p K a}} \\
\alpha_{1}=1-\alpha_{0}=\frac{10^{p H-p K a}}{1+10^{p H-p K a}}=\alpha_{0} 10^{p H-p K a}
\end{gathered}
$$

The subscript number zero is for most protonated species of the system and one for species with minus one proton. I will disregard activity coefficients for the simplicity of representation.

$$
\begin{aligned}
\alpha_{i} & =10^{i p H-\sum_{1}^{i} p K a_{j}}\left(\frac{1}{1+\sum_{1}^{N} 10^{i p H-\sum_{1}^{i} p K a_{j}}}\right) \\
& =\alpha_{0} 10^{i p H-\sum_{1}^{i} p K a_{j}}
\end{aligned}
$$

\section{EXAMPLES}

The two examples will be shown. One with only one Bronsted Acid-Base System and other with more than one polyprotic system.

\section{Example 1}

Let's consider a diprotic system with different species in solution. $\mathrm{H}_{2} \mathrm{~A}$ represents the most protonated species. This system can be alone or with other acid-base equilibria in solution.

The Acid-base Bronsted-Lowry species are represented by equations:

$$
\begin{aligned}
& H_{2} A_{(a q)} \leftrightharpoons H A_{(a q)}^{-}+H_{(a q)}^{+} \\
& H A_{(a q)}^{-} \leftrightharpoons A_{(a q)}^{2-}+H_{(a q)}^{+}
\end{aligned}
$$

$p K a_{1}$

$p K a_{2}$

The Eqs 5-8 describe the matter balance and fractions of equilibrium.

$$
\begin{gathered}
c\left(H_{2} A\right)=c\left(H A^{-}\right)=c\left(A^{2-}\right)=\left[H_{2} A\right]+\left[H A^{-}\right]+\left[A^{2-}\right] \\
\alpha_{0}=\frac{\left[H_{2} A\right]}{c\left(H_{2} A\right)} \\
\alpha_{1}=\frac{\left[H A^{-}\right]}{c\left(H_{2} A\right)} \\
\alpha_{2}=\frac{\left[A^{2-}\right]}{c\left(H_{2} A\right)}
\end{gathered}
$$

It is possible to observe that in a specific $\mathrm{pH}-\mathrm{a}$ solution or value I want to adjust - the equilibrium fractions could be directly calculated. If the analytical concentration is known (it is very common), then all equilibria concentrations could be directly calculated. And that is all!! Again, there is no need to calculate $\mathrm{pH}$ since it can be directly measured. However, knowing the equilibrium concentrations of each possible species is also important (and easy, using this method). Calculating equilibrium fraction is just a much less important stage.

It is easy to understand the great importance of the diagram of the distribution of species (in a Bronsted acid-base system). I can select a $\mathrm{pH}$ or range of $\mathrm{pH}$ where a certain species will be in higher or lower equilibrium concentration, depending on the analytical problem. One example of the monoprotic system (acetic acid) is given Figure 1a; a triprotic system (citric acid) is presented in Figure 1b.

The last equation of the Equilibrium Triad presented here is the Charge Balance. It will be useful to relate all systems in a solution. The $\mathrm{pH}$ of the solution affects all acid-base equilibria, and it is also affected by all present species in (or added to) the solution. This property is very important, but few times presented in textbooks. All calculations about buffer effects could be done with this equation. With it, there is no need to use the equation of Henderson-Hasselbalch, and the problems with approximations or odd situations will disappear. In fact, the Henderson-Hasselbalch equation, proposed in begin of the XX century, could become just a historical equation.

The balance of charge will be adequately expressed as the difference between the positive charge equilibrium concentration and the negative one must be equal to zero (Eq. 9).

$$
[+]-[-]=0
$$

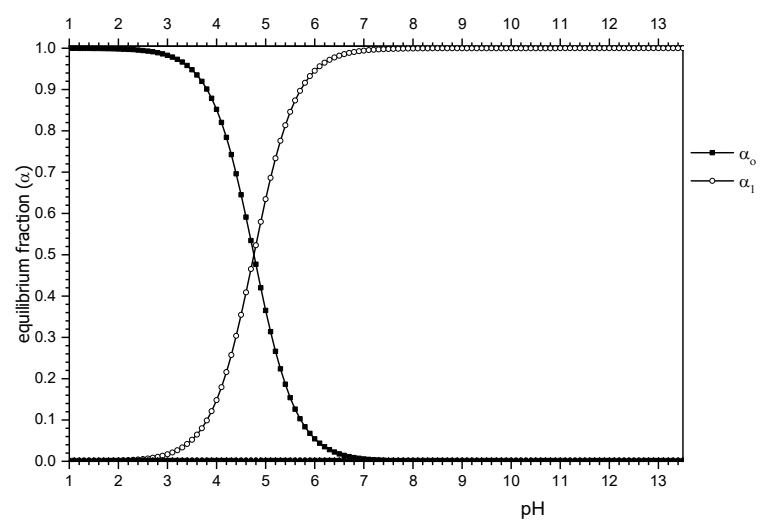

(A)

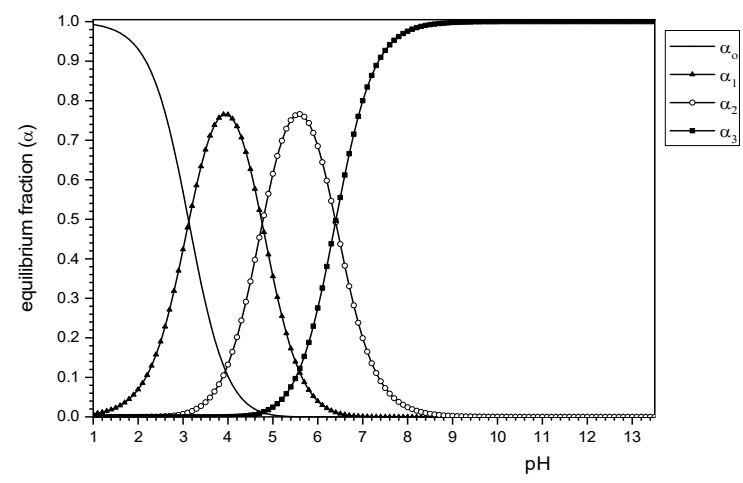

(B)

Figure 1: Diagrams of the Distribution of Species for Bronsted acid-base systems. (A) acetic acid; (B) citric acid

It is possible to demonstrate (but here, unfortunately) that equation is also expressed by Eq. 10 (Oliveira, 2020).

$$
\sum q(i)[i]=0
$$

\section{Example 2}

A solution of citric acid $0.02 \mathrm{~mol} \mathrm{~L}^{-1}$ and sodium dihydrogen phosphate $0.01 \mathrm{~mol} \mathrm{~L}^{-1}$ had the $\mathrm{pH}$ adjusted to 4.5 (without significantly changing its volume, for simplicity of calculation) with a strong monoprotic acid (or base). I want to know if an acid or base was used and its concentration in the final solution for this adjustment of $\mathrm{pH}$.

The chemical equations are shown, where citric acid was represented by $\mathrm{H}_{3}$ cit. 


$$
\begin{aligned}
& \mathrm{H}_{2} \mathrm{O}_{(l)} \rightleftharpoons H_{(a q)}^{+}+\mathrm{OH}_{(a q)}^{-} \\
& \left.\mathrm{Hcit}^{2-}(a q) \leftrightharpoons \mathrm{Ki}_{(a q)}^{+}+\mathrm{cit}^{3-}{ }_{(a q)}\right) 14.00 \\
& \mathrm{NaH}_{2} \mathrm{PO}_{4}(s) \rightarrow \mathrm{Na}_{(a q)}^{+}+\mathrm{H}_{2} \mathrm{PO}_{4}{ }^{2-}{ }_{(a q)} \\
& \mathrm{H}_{3} \mathrm{PO}_{4(a q)} \rightleftharpoons \mathrm{H}_{(a q)}^{+}+\mathrm{H}_{2} \mathrm{PO}_{4}^{-}(a q) \\
& H_{3} \text { cit }_{(a q)} \leftrightharpoons H_{(a q)}^{+}+H_{2} \text { cit }_{(a q)} \\
& \mathrm{H}_{2} \mathrm{cit}_{(a q)}^{-} \leftrightharpoons \mathrm{H}_{(a q)}^{+}+\mathrm{Hcit}_{(a q)}^{2-} \\
& \mathrm{H}_{2} \mathrm{PO}_{4}^{-{ }_{(a q)}} \rightleftharpoons \mathrm{H}_{(a q)}^{+}+\mathrm{HPO}_{4}{ }^{2-}(a q) \\
& \mathrm{HPO}_{4}{ }^{2-}{ }_{(a q)} \mathrm{HtI}^{+}{ }_{(a q)}+\mathrm{PO}_{4}{ }_{(a q)} 3.128 \\
& \mathrm{pKa}_{2} \quad 4.761
\end{aligned}
$$

The balance of charge of this solution was

$$
\left[\mathrm{H}^{+}\right]-\left[\mathrm{OH}^{-}\right]+\left[\mathrm{Na}^{+}\right]-\left[\mathrm{H}_{2} \mathrm{Cit}^{-}\right]-2\left[\mathrm{Hcit}^{2-}\right]-3\left[\mathrm{cit}^{3+}\right]-\left[\mathrm{H}_{2} \mathrm{PO}_{4}^{-}\right]-2\left[\mathrm{HPO}_{4}^{2-}\right]-3\left[\mathrm{PO}_{4}^{-}\right]+q_{x} \mathrm{c}_{x}=0
$$

Where $\mathrm{q}_{\mathrm{x}} \mathrm{c}_{\mathrm{x}}$ is the term associated with strong acid or base in the medium. The key to the solution of the problem is the solution already is done, so the proton and hydroxyl concentration are determined (and they determinate the $\mathrm{pH}$ ), and the counterion is the unknown species. Once the signal of this term is determinated, it is possible to say was used a strong acid or a base for adjusting the solution.

Using 'cit' for referring to the citrate system and 'fosf' to the phosphate system, and $\mathrm{c}\left(\mathrm{Na}^{+}\right)$is equal to analytical concentration of phosphate

$$
\begin{gathered}
10^{-p H}-10^{p H-p K w}+c\left(N a^{+}\right)-\alpha_{1}(\mathrm{cit}) \cdot c(\mathrm{cit})-2 \alpha_{2}(\mathrm{cit}) \cdot c(\mathrm{cit})-3 \alpha_{3}(\mathrm{cit}) . c(\mathrm{cit})-\alpha_{1}(\text { fosf }) . c(\text { fosf }) \\
-2 \alpha_{2}(\text { fosf }) \cdot c(\text { fosf })-3 \alpha_{3}(\text { fos }) \cdot c(\text { fosf })=-q_{x} c_{x}
\end{gathered}
$$

A further possible rearrangement is to propose effective charge of acid-base system $\left(\mathrm{q}_{\mathrm{e}}\right)$ and Wat functions

$$
\begin{gathered}
q_{e}=\sum q_{i} \alpha_{i} \\
W a t=\left[H^{+}\right]-\left[O H^{-}\right]
\end{gathered}
$$

$W a t+c\left(N a^{+}\right)+\left[-\alpha_{1}(c i t)-2 \alpha_{2}(c i t)-3 \alpha_{3}(c i t)\right] c(c i t)+\left[-\alpha_{1}(\right.$ fosf $)-2 \alpha_{2}($ fosf $\left.)-3 \alpha_{3}(f o s f)\right] c(f o s f)=-q_{x} c_{x} \Rightarrow$

$$
W a t+c\left(N a^{+}\right)+q_{e}(\text { cit }) c(c i t)+q_{e}(\text { fosf }) c(\text { fosf })=-q_{x} c_{x} \Rightarrow
$$
2020).

The values of $\alpha$ 's, Wat and $\mathrm{q}_{\mathrm{e}}$ in $\mathrm{pH} 4.5$ are shown in Table 1, which were calculated with DistCalc Excel spreadsheet (Oliveira,

Finally, the term $\mathrm{q}_{\mathrm{x}} \mathrm{c}_{\mathrm{x}}$, after adequate replace, will be equal to $-0.0264 \mathrm{~mol} \mathrm{~L} \mathrm{~L}^{-1}$. It indicates that $\mathrm{q}_{\mathrm{x}}$ is negative, and the counterion is an anion. So, it was used a strong acid for adjusting of solution $\mathrm{pH}$, in way to keep its analytical concentration of $0.0364 \mathrm{~mol} \mathrm{~L}^{-1}$. Of course, experimentally, the $\mathrm{pH}$ value should be monitored during the adjust, due experimental variations.

Table 1 - Values of the parameter for solution of Example 2 in $\mathbf{p H} 4.5$.

\begin{tabular}{|l|c|c|c|c|c|}
\hline System & $\alpha_{0}$ & $\alpha_{1}$ & $\alpha_{2}$ & $\alpha_{3}$ & $\mathrm{q}_{\mathrm{e}}$ \\
\hline Citrate & 0.0266 & 0.6264 & 0.3426 & 0.0044 & -1.3248 \\
\hline Phosphate & $4.42 .10^{-3}$ & 0.9936 & 0.0020 & 0.0000 & -0.9976 \\
\hline $\mathrm{pH}$ & 4.5 & Wat $/\left(\mathrm{mol} \mathrm{L}^{-1}\right)$ & $3,162.10^{-5}$ & & \\
\hline
\end{tabular}

\section{CONCLUSION}

The simple change of view of an aqueous solution, the $\mathrm{pH}$ of solutions is known, permits to change in all teaching of acid-base equilibrium. Important parameters are defined and use, as effective electrical charge. The amount of substance for adjust of $\mathrm{pH}$ can be easily calculated, and so, buffer solutions. In this paper, I just have shown a piece of the myriad of applied problems to be resolved using a more comprehensible approach, with less calculation, and without needing approximations.

\section{ACKNOWLEGDMENT}

I am very thankful to my colleagues who encouragement to develop this new view in a new method for the study of the chemical solutions. And to Marcos Flores Jr. also for revision of this text. 


\section{R E F E R E N C E S}

Uribe, D. Solving Chemical Equilibrium. J.Chem Ed. 1998, 75(9), 1177-1179;DOI: 10.1021/ed075p1177.

Matsumoto, P. S.; Tong G.; Lee, S.; Kam, B The Use of Approximations in a High School Chemistry Course $J$. Chem. Educ., 2009, 86 (7), 823-826; DOI: 10.1021/ed086p823.

Matsumoto, P.S.: The Reaction Quotient Is Unnecessary to Solve Equilibrium Problems J. Chem. Educ., 2005, 82 (8), 1149-1150, DOI: 10.1021/ed082p1150.

Pardue, H. L.; Odeh, I. N.; Tesfai, T. M. Unified Approximations: A New Approach for Monoprotic Weak Acid-Base Equilibria J. Chem. Educ., 2004, 81 (9), 1367-1375; DOI: 10.1021/ed081p1367.

Cepriá, G; Salvatella, L. General Procedure for the Easy Calculation of $\mathrm{pH}$ in an Introductory Course of General or Analytical Chemistry J. Chem. Educ., 2014, 91 (4), 524-530; DOI: 10.1021/ed400089j.

Glaser, R.E.; Delarosa, M. A.; Salau, A. O.; Chicone, C. Dynamical Approach to Multiequilibria Problems for Mixtures of Acids and Their Conjugated Bases. $J$. Chem. Educ., 2014, 91 (7), 1009-1016. DOI: 10.1021/ed400808c.

Bellová, R; Melicherčíková, D., Tomčík, P. Approximate Relations in $\mathrm{pH}$ Calculations for Aqueous Solutions of Extremely Weak Acids: A Topic for Problem-Based Learning. J. Chem. Educ., 2018, 95(9), 1548-1553. DOI: $10.1021 /$ acs.jchemed. 8 b00086.

Po, H. N.; Senozan, N. M. The Henderson-Hasselbalch Equation: Its History and Limitations. Journal of
Chemical Education, 78(11), 2001, 1499-1503; DOI:10.1021/ed078p1499.

Harris, D.C.; Quantitative Chemical Analysis, 7th ed.; Freeman: N.York, 2006, caps. 6-10.

Skoog, D. A.; West, D. M.; Holler, F.J.; Crouch, S. Fundamentals of Analytical Chemistry, 9th ed.; Thomson: N.York, 2013, cap. 9.

Clark, W.M. Determination of Hydrogen ion, 2nd ed, Williams \& Wilkins: Baltimore, 1922.

Szabadvary, F.; Osper, R. E. Development of the $\mathrm{pH}$ concept: A historical survey $J$. Chem. Ed., 1964, 41(2) 105 DOI: 10.1021/ed041p105.

Science History Institute https://www.science history.org/historical-profile/arnold-o-beckman., 2017. (accessed Oct 2019)

Oliveira, A. F. Chemical Equilibria in Aqueous Solution oriented to applications, Atomo: Campinas, 2009 (in Portuguese).

Oliveira A. F. Chemistry of Solutions: Evaluation of Chemical Equilibria in Aqueous Solutions, EdUFV: Viçosa, 2020 (in press) (in Portuguese)

Oliveira, A. F.; Pereira R. L.; Flores-Jr, M,; Neves, A. A.; Queiroz, M. E. L. R. Description of process in aqueous solutions: differences between XIX and XX Centuries conceptions. The Journal of Engineering and Exact Sciences, 2019, 5(1). DOI: https: 10.18540/jcecvl5iss1pp0020-0025.

Oliveira, A. F., https://en.solucaoquimica.com/ download (accessed april 2020). 